\title{
The Jesuit António Vieira on Paul's Judeo-Gentile Universalism and Jewish Resiliency
}

\author{
Claude B. Stuczynski \\ Bar-Ilan University, Department of General History, Ramat Gan, Israel \\ claude.stuczynski@biu.ac.il
}

\begin{abstract}
This article reassesses António Vieira's views on New Christians and Jews. Rather than presenting a reductive portrait of Vieira's philosemitism as merely empathic, positive, and tolerant, I argue that his supportive attitudes included some enduring negative ideas of Jewishness. An analysis of Vieira's pro-converso and prophetic writings (including his Inquisition trial) show that his more ambivalent and dialectical perceptions were ultimately grounded on a theological-political interpretation of Paul's Judeo-Gentile universalism.
\end{abstract}

\section{Keywords}

António Vieira - Portugal - conversos - Jews - St. Paul - philosemitism - universalism - soteriology - Gonçalo Anes Bandarra

\section{Atlantic Alternations and Judeo-Gentile Concerns}

The Portuguese Jesuit António Vieira (1608-97) is one of the most intriguing figures in the long and complex history of Jesuit-Jewish/converso relations. ${ }^{1} \mathrm{He}$ lived a long, rich, and engaged life, regularly traversing the Atlantic: to colonial

James Bernauer and Robert A. Maryks, eds., "The Tragic Couple": Encounters between Jews and Jesuits (Leiden: Brill, 2014). On Vieira, the New Christians, and the Jews, see the overviews: Anita Novinsky, "Padre Antonio Vieira, the Inquisition, and the Jews," Jewish History 6 (1992): 151-62; Arnaldo Niskier, Padre Antônio Vieira e os Judeus (Rio de Janeiro: Imago, 2004). 
Bahia; serving in the court of King John IV (1604-56; r.1640-56) in Lisbon; traveling to France, England, the Netherlands, and Italian peninsula as a diplomatic emissary of the Portuguese monarch; sailing the Amazon River; secluded in Coimbra as a prisoner of the Inquisition; pleading his own and others' cases before the Holy See in Rome; preaching in the rain forests of Maranhão. ${ }^{2}$ Although he was not a converso, he became the leading voice supporting the integration of the New Christian "Men of the Nation" (homens da nação) into Portuguese society, fighting relentlessly against the local Inquisition for "fabricating Jews" out of many innocent Catholics. ${ }^{3}$ Under his leadership, part of the Society of Jesus in Portugal, which had been notorious for its anti-converso policies, became associated with the converso cause. This was true despite the fact that the Society was still divided about New Christians, sometimes putting Vieira at odds with his confrères. ${ }^{4}$ In 1649, following Vieira's suggestion, the General Company of Commerce of Brazil was founded to promote the New Christian entrepreneurial elites and protect the converso nação from having their belongings confiscated by the Holy Office. ${ }^{5}$ Between 1674 and 1681, Vieira was instrumental in obtaining from the pope an eight-year suspension of Portugal's Inquisition on grounds of arbitrariness. ${ }^{6}$ During his diplomatic mission on behalf of King John IV in the 1640 , he met leading converso figures in western France and ex-converso Sephardic personalities in the Netherlands,

2 The bibliography on Vieira is extensive and growing. It will suffice here to mention three comprehensive biographies: Jõao Lúcio de Azevedo, História do Padre António Vieira, com factos e documentos novos, 2 vols. (Lisbon: Livraria Clássica, 1918-20); Thomas M. Cohen, The Fire of Tongues: António Vieira and the Missionary Church in Brazil and Portugal (Stanford: Stanford University Press, 1998); Ronaldo Vainfas, Antônio Vieira: Jesuita do rei (São Paulo: Companhia das Letras, 2011).

3 Herman Prins Salomon, "A Little-Known Gibe at the Inquisition by Father António Vieira (1608-1697)," in Portuguese Jews, New Christians and "New Jews": A Tribute to Roberto Bachmann, ed. Claude B. Stuczynski and Bruno Feitler (Leiden: Brill, 2018), 145-73.

António Borges Coelho, "Tradição e mudança na política da Companhia de Jesus face à comunidade dos cristãos-novos," Revista de história 10 (1999): 87-94; Claude B. Stuczynski, "Negotiated Relationships: Jesuits and Portuguese Conversos: A Reassessment," in Tragic Couple, 43-61.

Charles R. Boxer, "Padre Antonio Vieira, S.J., and the Institution of the Brazil Company in 1649," The Hispanic American Historical Review 29 (1949): 474-97; Israel-Salvator Révah, "Les jésuites portugais contre l'Inquisition: La campagne pour la fondation de la Compagnie Générale du Brésil (1649)," in Études portugaises, ed. Charles Amiel (Paris: Fundação Calouste Gulbenkian, Centro Cultural Português, 1976), 155-83.

6 Ana Maria Homem Leal de Faria, "Uma 'teima' do confronte de poderes ao malogro da reforma do Tribunal do Santo Ofíco: A suspensão da Inquisição Portuguesa (1674-1781)," in Inquisição portuguesa: Tempo razão e circumstância, ed. Luís Filipe Barreto et al. (Lisbon: Prefácio, 2007), 77-105; Giuseppe Marcocci and José Pedro Paiva, História da Inquisição Portuguesa, 1536-1821 (Lisbon: A Esfera dos Livros, 2013), 201-9. 
including Rabbi Manasseh ben Israel (1604-57). Such encounters took place in the context of his mercantilist efforts and "millenarian" hopes to lure prosperous exiled Portuguese New Christians and ex-converso "New Jews" back to their motherland, who would then purportedly help to restore Portugal's lost grandeur. ${ }^{7}$ Vieira addressed numerous letters to kings and popes on behalf of the New Christians. Additionally, he was reputed to have authored influential tracts against the Portuguese Holy Office, such as the Notícias recônditas and the Gravamina. ${ }^{8}$ At the same time, he was a committed missionary in the tropics and a passionate defender of Brazil's Amerindians against enslavement and brutal exploitation. ${ }^{9}$ Although he did not question the Atlantic slave trade, he called for better treatment of the black African slave population..$^{10}$ In his lifetime, he was recognized as a gifted writer and a charismatic preacher. Even within the Sephardic community of Amsterdam, his sermons were invoked with sympathy and admiration. ${ }^{11}$

Vieira was a firm believer in Portugal's providential role in history, advocating the idea that the reign of Christ would be fulfilled on earth through the so-called Fifth Empire before the end of times, as foretold in the Book of Daniel. ${ }^{12}$ This moment of Christian plenitude would be led by a Portuguese "hidden king," as proclaimed by the popular prophet and shoemaker of Trancoso, Gonçalo Anes Bandarra (1500-56), in his prophetical ballads or Trovas. ${ }^{13}$ Whereas the latter

On Vieira's encounter with ben Israel, see António José Saraiva, "António Vieira, Menasseh ben-Israel et le Cinquième Empire," Studia Rosenthaliana 6 (1972): 25-56; Natalia Muchnik, "António Vieira y la diáspora sefardí en el siglo XVII," in António Vieira: Roma e o universalismo das monarquias portuguesa e espanhola, ed. Pedro Cardim and Gaetano Sabatini (Lisbon: Universidade Nova de Lisboa, 2011), 97-119; Florence Lévi, "Messianisme et prophétie chez le jésuite António Vieira et le rabbin Menasseh ben-Israël," Sigila 37 (2016): 31-48.

8 Herman Prins Salomon, ed., Queimar Vieira em Estátua: As Apologias $(1738,1743)$ do Senhor Inquisidor António Ribeiro de Abreu em resposta às Notícias recônditas atribuídas ao pe. António Vieira (1608-1697) (Lisbon: Cátedra de Estudos Sefarditas Alberto Benveniste; Rede de Judiarias de Portugal, 2014).

Charlotte de Castelnau-L'Estoile, "Salvar-se, salvando os outros: O padre António Vieira, missionário no Maranhão 1652-1661,” Océanos 30-31 (1997): 55-64. Magno Vilela, Uma questão de igualdade ... António Vieira: A escravidão negra na Bahia do século XVII (Rio de Janeiro: Relume Dumará, 1997). Harm den Boer, La literatura sefardí de Amsterdam (Alcalá de Henares: Instituto Internacional de Estudios Sefardíes y Andalusíes, Universidad de Alcalá, 1995), 23.

Raymond Cantel, Prophétisme et messianisme dans l'oeuvre d'António Vieira (Paris: Ediciones Hispano-Americanas, 1960); António Lopes, Vieira o Encoberto (Cascais: Principia, 1999); Maria Ana Travassos Valdez, Historical Interpretations of the "Fifth Empire": The Dynamics of Periodization from Daniel to António Vieira, S.J. (Leiden: Brill, 2011). 2014), 135; António Vieira, Defesa perante o Tribunal do Santo Ofício, ed. Paulo Borges (Lisbon: Círculo de Leitores, 2014), 180-81. 
aspect was elaborated in Vieira's Esperanças de Portugal (Hopes of Portugal) and História do futuro (History of the future), his account of the forthcoming reign of Christ on earth was set forth in his unfinished magnum opus, the Clavis prophetarum (Key of prophets). ${ }^{14}$ Vieira held a prophetic understanding of history, which implied that the dialectical interplay between Jews and Gentiles depicted by St. Paul (c.5-c.64) in the Epistle to the Romans, chapter 11, would be a major force in the advancement of humankind's salvation. In this providential vision, Judeo-Gentile tension would continue until the last and supreme moment of human history: the Fifth Empire. ${ }^{15}$ After the "destruction" of the Turks and Islam, both Jews and Gentiles would be spiritually saved in this final historical stagethe former through sincere and total conversion to the Catholic faith, and some of the "barbarous heathens" among the latter, also by virtue of their "invincible ignorance."16

Previous scholarship has painted a shifting portrait of Vieira. João Lúcio de Azevedo famously claimed that, during his long and intensely engaged life, he assumed six distinct roles: priest, politician, missionary, prophet, rebel, and visionary. Today, no scholar would endorse such a compartmentalized biographical narrative. ${ }^{17}$ Nonetheless, I believe that the emerging portrait of Vieira, multifaceted and more complex, deserves further exploration. I suggest that his alternating concerns with Brazil's Amerindians and Portuguese

Silvano Peloso, Antonio Vieira e l'impero universale: La "Clavis prophetarum" e $i$ documenti inquisitoriali (Viterbo: Sette Città, 2005); Ana T. Valdez, "Vieira between History of the Future and Clavis prophetarum," in Visions, Prophecies and Divinations: Early Modern Messianism and Millenarianism in Iberian America, Spain and Portugal, ed. Luis F. S. Lima and Ana Paula T. Megiani (Leiden: Brill, 2016), 215-29; Valdez, "António Vieira and the Fifth Empire: A New Light from the Clavis prophetarum," in Estudos sobre o Padre António Vieira, ed. Arnaldo Espírito Santo et al., 2 vols. (Lisbon: Imprensa Nacional-Casa da Moeda, 2017), 2:331-59.

Although for Paul, the massive conversion of Gentiles was aimed to arouse "envy" among Jewish unbelievers, Vieira suggested that after the final conversion of the Jews, the former would probably become jealous of the latter. Cf. António Vieira, Apologia, ed. Adma Muhana (Lisbon: Círculo de Leitores, 2014), 138-43.

16 António Vieira, A Chave dos profetas, Livro Segundo e Livro Terceiro, ed. Pedro Calafate (Lisbon: Círculo de Leitores, 2014), 414-38 (= Silvano Peloso, La Clavis prophetarum di Antonio Vieira: Storia, documentazione e ricostruzione del testo sulla base del ms. 706 della Biblioteca Casanatense di Roma [Viterbo: Sette Città, 2011], 415-28). Vieira's Judeo-Christian views entailed implicit and explicit "Islamophobia," mostly stemming from his Joachimite penchants. See Claude B. Stuczynski, "What Does 'Judeo-Christianity' Mean in Late Medieval and Early Modern Iberia?," Cadernos de estudos sefarditas 20 (2019): 11-34.

17 Alcir Pécora, "Retórica de uma biografia: Padre António Vieira por João Lúcio de Azevedo," Revista chilena de literatura 85 (2013): 271-92. 
New Christians and ex-converso Sephardi Jews were in part an outgrowth of his particular prophetic beliefs, which were in turn strongly related to Paul's soteriology. 18

Moreover, in his attempts to decipher Paul's Judeo-Gentile interplay, Vieira assumed some distinctly "Jewish" traits, which he surmised would persist over time and religious conversion. The most prominent of these characteristics was a "Jewish" ability to thrive in commerce. This article aims to resolve what at first glance might be perceived as a paradox: How is it possible that this iconic Jesuit champion of converso integration and friend of Jews could uphold such views of Jewishness? How could Vieira reconcile the idea of enduring Jewish traits with Paul's leitmotif: "There is neither Jew nor Greek [...] for you are all one in Christ Jesus?" (Galatians 3:28, Romans 10:12, Ephesians 2:11-22) As I claim in the following pages, this conundrum was a theological-political problem, which largely stemmed from Vieira's reading of Paul's Epistles through the prism of Bandarra's and others' prophetic interpretations of history. Thus, against a simplistic perception of Vieira's philosemitism, I claim that his engagement on behalf of New Christians and open Jews was necessarily mixed with negative views and premises.

\section{Economy and Salvation}

It is well known among scholars that in the letters addressed by Vieira to King John IV in the 1640s, Portuguese New Christians and ex-converso Sephardi Jews were associated with their successful commercial activities and entrepreneurial skills, "being no better men with wealth and eagerness than those of the nation."19 Despite "having in their hands most of the commerce and wealth of the world," he wrote, a majority of them lived scattered around the globe, longing to return to their beloved motherland. ${ }^{20}$ Vieira argued that it was a fact that many of these useful Christian denizens, so vital to Portugal's economic and political recovery, left their birth land out of fear of inquisitorial persecution and "purity of blood" exclusion, and some of them even went on to adopt Judaism publicly_while Portugal was known for its acts of courage, sacrifice,

18 Florence Lévi, "O Padre António Vieira (16o8-1697) e os judeus: As referências a São Paulo," in Identidade e cidadania: Como se expressa no judaísmo brasileiro, ed. Helena Lewin (Rio de Janeiro: Programa de Estudos Judaicos, 2005), 173-81. 
and martyrdom in India, Japan, and China, aimed to bring Christianity to distant lands and peoples. ${ }^{21}$

In order to put to an end to this paradoxical situation, our Jesuit called to reform Portugal's harsh and biased Holy Office on the model of the milder and more reliable inquisitions of Castile and Rome and readmit exiled New Christians and ex-converso Sephardi Jews into the kingdom. In this way, he hoped that Lisbon would become "the greatest empire in the world." Vieira acknowledged that some degree of toleration would be required to deal with the eventual religious misbehavior of some of the returnees. Thus, he called to erect a ghetto in Lisbon, as was the case in papal Rome. In general, however, he claimed that it was preferable to accept the risks of readmitting some exiled heretics and Jews rather than continue to let them supply their economic know-how to the Protestant countries and other enemies of Portugal and the Catholic Church. By returning to Portugal, they would financially sustain the kingdom against its foes and indirectly aid its onerous missionary efforts overseas. ${ }^{22}$ Moreover, over time, such hospitable conditions would encourage Jews and converso Judaizers to embrace Catholicism with conviction. ${ }^{23}$ In other words, mercantilism was the means through which Vieira envisioned the positive role to be played by New Christians and ex-converso open Jews as economic agents of Portugal's Catholic empire and as inadvertent promoters of their own and others' spiritual salvation. Vieira came to this conclusion through a combination of pro-converso economic views and Pauline soteriology.

I now wish to focus on two Pauline aspects of Vieira's mercantilism. On the one hand, his abovementioned project of repatriation implied that a gradual and non-coercive evangelization of the returnees would be slow. On the other hand, this lengthy conversion process did not overly disturb him. In the times of Jesus Christ, Vieira recalled, preaching was mainly addressed to the Jewish people; in this context, he quoted Jesus's negative answer to a Canaanite woman: "I am not sent but unto the lost sheep of the house of Israel" (Matthew 15:24). However, when Saul/Paul of Tarsus was called by God to become the apostle to the Gentiles, non-Jews became the main focal point of evangelical activities. As a trained Jesuit, Vieira may have inferred from these first moments in the history of the church that God was calling missionaries to adopt targeted

\footnotetext{
$21 \quad$ Vieira, Escritos sobre os judeus e a Inquisição, $5^{2}$.

22 "If the money of the men of the nation sustain the armies of the heretics to sow and spread the sects of Calvin and Luther, is it not a greater service to God and the Church to employ that same money to arm a most Catholic king to spread and expand around the world the law and the faith of Christ?" (Vieira, Escritos sobre os judeus e a Inquisição, 44, 66). 
strategies of evangelization: "Whoever is commissioned by God to gain the faith of a nation (nação), he must proceed efficaciously, even if this could neatly damage the faith of the other [nation]." That said, he recalled that such missionary alternation was originally intended by Paul for Jews and Gentiles as a "mystery" ( $\mu \nu \sigma \tau$ ńp $10 v)$ of God's salvation of mankind (Romans 11:25).

It is true that throughout the long history of the church, individuals and small groups of Jews had successfully joined Christianity with fervor, noted Vieira. This trickling phenomenon of conversions proved how un-Christian it was to exclude conversos in toto on an ethnic basis. He also acknowledged that within the heterogeneous group, he personally knew many devoted Catholics along with heretic Judaizers. ${ }^{24}$ However, he believed that until the Fifth Empire, sincere Jewish conversion to Christianity was destined to remain a relatively circumscribed phenomenon compared to the massive evangelization of Gentiles. Therefore, Romans 11 revealed that from Paul's times to the Fifth Empire, the main missionary task would be to bring the non-Jewish masses into the Christian fold "until the full number of the Gentiles has come in" (Romans 11:25). During this period of time, Jewish conversion appeared mostly to bear a promise, a hope, and a warranty that Christianity would never abandon its all-inclusive and universalist commitments.

As previously mentioned, Vieira maintained that Portugal was elected by God to be a new and upgraded "chosen people." ${ }^{5}$ The task of the Portuguese, however, was different than the role played by the biblical Hebrews. Theirs was to complete Paul's evangelical mission among non-Christian infidels and heretics, and especially among Gentile "pagans" living in remote parts of the world.$^{26}$ In order to justify this claim, he evoked the by-then locally widespread account of Jesus's miraculous revelation to the founder of Portugal's monarchy, King Afonso Henriques (r.1139-85), during the battle of Ourique of 1139: "I am the founder and destroyer of kingdoms and empires, and I desire in you and in your descendants to found for myself a kingdom, by which means my name will be known in far-off nations." ${ }^{27}$ In Vieira's incisive language, the so-called

24 Vieira, Escritos sobre os judeus e a Inquisição, 55-56, 218-25. Cf. Vieira, Apologia, 137.

25 Maria V. Jordán, "The Empire of the Future and the Chosen People: Father António Vieira and the Prophetic Tradition in the Hispanic World," Luso-Brazilian Review 41 (2003): 46-57.

26 See Claude B. Stuczynski, "Providentialism in Early Modern Catholic Iberia: Competing Influences of Hebrew Political Traditions," Hebraic Political Studies 3 (2008): 377-95; Stuczynski, “Iberian Expansion and 'Political Paulinism," Zemanim 118 (2012): 74-82. António Brandão, Terceira parte da monarchia lusitana que contem a historia de Portugal desdo Conde Dom Henrique, até todo o reinado del rey Dom Afonso Henriques (Lisbon: Pedro Craesbeck, 1632), 120. 
"miracle of Ourique" meant "that God sent Portugal to this world not to spread the faith among the Jews, but to obtain the conversion of the Gentiles." ${ }^{28}$

King Manuel I's (r.1495-1521) successful imperial and evangelical enterprises overseas were for the Jesuit tangible proof of Portugal's divine election. It is no wonder, then, that this monarch preferred to support far-flung discoveries and missionary activities rather than addressing the question of the expelled Jews from Spain living in his kingdom. At the same time, the king's 1497 decision to baptize Portugal's Jews, coupled with legislation intended to ensure their integration as full-fledged Christians, explains the fact that during his reign Portugal "attained its greatest happiness." 29 Along with ulterior measures taken by the subsequent monarch John III (1502-57; r.1521-57)) in favor of New Christian businessmen and entrepreneurs, these acts for Vieira indicated the existence of "a hidden provision made by Divine Providence: that it is not displeased that Catholic monarchs will be merciful and clement towards these men." Conversely, King Sebastian's (1554-78; r.1557-78) disavowal of that policy led to "sixty years of tears," when the Spanish-Habsburg kings became Portugal's masters (1580-1640). ${ }^{30}$

Accordingly, it was not only the converso and Jewish economic contribution that was vital to ensure the "conservation of this kingdom [...], helping very much to our holy faith." It was also God's wish that Portugal would be merciful to the nation, which counted among its members "the sacred apostles, and the most holy Virgin; and it was the blood that the Son of God chose to take as means to obtain our redemption and union with His Divinity."31 Moreover, he claimed that "besides being a principle of faith that this entire nation [i.e. the Jews] will be converted and know Christ, our prophecies tell this good news

Vieira, Escritos sobre os judeus e a Inquisição, 67. In his Livro anteprimeiro da história do futuro, Vieira expanded the task of overseas evangelization to the Infant Henry (1394-146o), later called "the Navigator," and to all those who took part in Portugal's maritime discoveries and expansion. Paraphrasing Habakkuk's prayer (Habakkuk 3:8), Vieira glossed: "Portuguese were those knights to whom Christ first opened the way of the seas $[\ldots]$ and the ships of the Portuguese were those chariots that bring by sea faith and salvation" (Vieira, História do futuro, ed. Pedro Calafate [Lisbon: Círculo de Leitores, 2014], 208).

29 Vieira, Escritos sobre os judeus e a Inquisição, 45.

30 Vieira, Escritos sobre os judeus e a Inquisição, 45-46.

31 Cf. António Vieira, Defesa perante o Tribunal do Santo Ofício, ed. Paulo Borges (Lisbon: Círculo de Leitores, 2014), 336-37. Similar arguments (including the consumption of Christ's Jewish body in the Eucharist) were invoked by the converso Cardinal Juan de Torquemada (1388-1468) against the exclusion of conversos in 1440s Toledo. See Benzion Netanyahu, The Origins of the Inquisition in Fifteenth-Century Spain (New York: Random House, 1995), 1110-12. 
as one among the prodigious outcomes of the miraculous kingdom of Your Majesty, because they said that the sons of Jacob will help the hidden king, and as a reward for this support, they will know the truth of Christ, recognizing and worshipping Him as God."32

This dense excerpt requires some unpacking. ${ }^{33}$ On the one hand, Vieira was following an almost universally accepted interpretation of the meaning of Paul's "all Israel will be saved" (Romans 11:26), as announcing the final, complete, and sincere conversion of the Jews to Christianity. ${ }^{34}$ On the other hand, he employed the prophetic Trovas of Bandarra, which were imbued with Pauline ideas and were particularly popular during the first stages of the Braganzas' dynastical "restoration" from the Habsburgs, ${ }^{35}$ to claim that a Portuguese salvific "hidden king," initially identified by Vieira with John IV, would lead to the total and sincere conversion of the "Jews," including the "Ten Lost Tribes of Israel."36 This would occur during the Fifth Empire, after the defeat of the Turks and Islam, when the "full number of the Gentiles has come in" (Romans 11:26). ${ }^{37}$

At the same time, by stating that the "sons of Jacob" would help the "hidden king," Vieira was referring to stanzas of the Trovas in which the shoemaker of Trancoso depicted a dialogue between two foreign Jews called "Fraim" and "Dão" (i.e., Ephraim and Dan) with a character named "Fernando" (for Vieira, a heteronym of the "hidden king"). ${ }^{38}$ Both Jews offered "expensive jewels [...], a big treasure/ a lot of silver, plenty of gold/ we bring from beyond the seas," in exchange

Vieira, Escritos sobre os Judeus e a Inquisição, 45.

33 For an alternative interpretation, see David L. Graizbord, "Philosemitism in Late-Sixteenth and Seventeenth-Century Iberia: Refracted Judeophobia?," The Sixteenth Century Journal 38 (2007): 665-69.

Vieira, Apologia, 151-54. Cf. Jeremy Cohen, "The Mystery of Israel's Salvation: Romans 11:25-26 in Patristic and Medieval Exegesis," Harvard Theological Review 98 (2005): 247-81. Francisco Bethencourt, "The Unstable Status of Sebastiansm," in Utopia in Portugal, Brazil and Lusophone African Countries, ed. Francisco Bethencourt (Oxford: Peter Lang, 2015), 43-69.

36 Richard H. Popkin, "The Lost Tribes, the Caraites and the English Millenarians," Journal of Jewish Studies 37 (1986): 213-27; Zvi Ben-Dor Benite, The Ten Lost Tribes: A World History (New York: Oxford University Press, 20o9).

"Everybody shall have a single love/ Gentiles as much as pagans/ Jews will become Christians/ Without ever finding error" (in Elias Lipiner, Gonçalo Anes Bandarra e os Critãos-Novos [Trancoso: Câmara Municipal de Trancoso, Associação Portuguesa de Estudos Judaicos, 1996], 218). This was one of Vieira's main arguments to reject accusations regarding the Jewish penchants of Bandarra's Trovas (Vieira, Apologia, 68, 131-54; Vieira, História do futuro, 357-74; Muhana, ed., Autos do processo de Vieira na Inquisição, 82, 85; Vieira, Defesa perante o Tribunal do Santo Ofício, 180).

38 Muhana, ed., Autos do processo de Vieira na Inquisição, 78-80, 229. 
for a meeting with the "Great Shepherd" (according to Vieira, the pope). ${ }^{39}$ These stanzas echoed the glamorous 1525 mission to Portugal of the "ambassador" of the king of the Ten Lost Tribes of Israel, David Ha-Reubeni (1490-c.1541), who purportedly came from beyond the legendary river of Sambatyon. ${ }^{40}$ According to Vieira, however, these Trovas also implied that at least from the times of King Manuel I onwards, Jews were a tool of providence destined to pave the way for the advent of the Fifth Empire. In other words: while Portuguese kings were spreading the Gospel through imperial expansion and mission in accordance with the prophecies foretold in the "Miracle of Ourique," the economic activities of the "the sons of Jacob" depicted by Bandarra would enable the advancement of that crowning moment of human history, the Fifth Empire, which would include their own and others' adherence to Christ. ${ }^{41}$

\section{Judeo-Gentile Interactions}

Vieira's prophetic writings, which, according to Adma Muhana, were in great measure composed as reactions to inquisitorial accusations such as the "Jewish" character of his and Bandarra's views, ${ }^{42}$ further clarify the meaning and implications of Vieira's stance as depicted in his letters. Employing baroque images of life, Vieira, the Jesuit preacher, admitted that "the history of the succession and achievements of the human genre, from the beginning of the world to its end, is anything but a comedy of God, performed in the theatre of this world." The dramatic personae of this comedy consisted of a rich variety of peoples, cultures, religions, and political regimes, each of which deserved to be understood and treated according to their own idiosyncrasies. That said, he stated once again that all of these "characters" were variations on the primordial couple revealed in Paul's Epistles: the Jews and the Gentiles,

Lipiner, Gonçalo Anes Bandarra e os Critãos-Novos, 202-23.

Elias Lipiner, O sapateiro de Trancoso \& o alfaiate de Setúbal (Rio de Janeiro: Imago, 1996). According to Vieira, King Manuel I's policy of spreading the Gospel among Gentiles without ignoring the Jews explains the disproportionate length of his arms, wishing to embrace both peoples all together (Vieira, Defesa perante o Tribunal do Santo Ofício, 567). Muhana, ed., Autos do processo de Vieira na Inquisição, 36. Cf. José van den Beselaar, Antônio Vieira: Profecia e polêmica (Rio de Janeiro: UERJ, 2002). Yet, Vieira's prophetic views evolved over time. Thus, in the Key of Prophets, Portugal's leading role in the salvation of mankind was minimized, the "hidden king" was not mentioned, and the concept of Christ's reign on earth was preferred to Daniel's Fifth Empire. See António Lopes, "Os 74 anos da evolução da 'utopia' de Vieira," in Terceiro centenário da morte do Padre Vieira: Congresso internacional, 3 vols. (Braga: Universidade Católica Portuguesa, Província Portuguesa da Companhia de Jesus, 1999), 2:857-97. 
who play "the two leading roles, or two main characters of this comedy," without ever leaving the historical scene. ${ }^{43}$ Jews and Gentiles were destined to play asymmetrical roles in history, noted Vieira. Whereas the latter are variegated, changing, and ephemeral (which explains why so many peoples, cultures, and civilizations merge, rise, fall, and disappear, sometimes without leaving any historical trace), ${ }^{44}$ the former were destined by Providence to remain a single cohesive people, despite the fact that they had almost always lived scattered as a despised minority. 45

Vieira was fully aware that according to a widespread Augustinian legacy, political subjection and geographical wanderings were a divine punishment to the Jews for having refused Christ as the promised Messiah. ${ }^{46}$ However, rather than merely reiterating St. Augustine's (354-430) more amicable perceptions of the Jewish people as God's cherished witness, ${ }^{47}$ like other Iberian pro-converso writers, he also revisited Paul's own Epistles in order to underscore their role in history. ${ }^{48}$ Until Abraham the patriarch, Vieira summarized, all of humanity was God's "chosen people." Due to vanity and idolatry, however, humans were

Vieira, Apologia, 176; Vieira, História do futuro, 371. Vieira was fully aware of the etymological and historical differences between the concept of Hebrews, which originally denoted the descendants of the biblical patriarch Eber, an ancestor of "Abraham the Hebrew" (Genesis 14:13); Israelites, as the scions of the patriarch Jacob or Israel; and Jews, either as members of the tribe of Judah or the inhabitants of the kingdom of Judah, which also comprised the members of the tribes of Levi and Benjamin. That said, he generally employed these terms as synonyms, preferring the term Jews, whether Christian believers or professing Jews. The same was true concerning the concept of Gentiles, understood by our Jesuit as non-Jews, although he admitted the difference between Christians, (Christian) heretics, Muslims, called by Vieira "pagans" (pagãos), and gentios, "understood for all the other members of gentility (gentilidade)" (Vieira, Apologia, 128, 164-65). As we shall see in greater detail, Vieira's atomization of these subcategories in the pairing of Jews and Gentiles stemmed from Paul's ecclesiology and soteriology.

Vieira, Apologia, 176. At the same time, Vieira argued, Jews were the most populous nation from "a single blood" (de um só sangue) (Vieira, História do futuro, 495; Vieira, Defesa perante o Tribunal do Santo Ofício, 316).

Vieira, Apologia, 174-77; Vieira, Defesa perante o Tribunal do Santo Ofício, 408-11. Regarding the "mystery" of the historical survival of the Jewish people, Vieira also brought the authoritative assessment of Justus Lipsius. See Justus Lipsius, Monita et exempla politica: Libri dvo, qui virtvtes et vitia principum spectant (Antwerp: Ioannes Moretus, 16o5), 21-22. Jeremy Cohen, Living Letters of the Law: Ideas of the Jews in Medieval Christianity (Berkeley: University of California Press, 1999), 19-66. Paula Fredriksen, Augustine and the Jews: A Christian Defense of Jews and Judaism (New York: Doubleday, 2008).

48 Claude B. Stuczynski, "Pro-Converso Apologetics and Biblical Exegesis," in The Hebrew Bible in Fifteenth-Century Spain: Exegesis, Literature, Philosophy, and the Arts, ed. Jonathan Decter and Arturo Prats (Leiden: Brill, 2012), 151-76. 
divided by "nations" and then superseded by the divine election of Abraham and one line of his carnal offspring: the sons of Jacob, also known as Israel. After God's incarnation, however, this election was provisionally transferred to the Gentiles, since only a minority of Israel's offspring did not reject Christ.

At the same time, our Jesuit relied on Paul's recurring answer in Romans 11 (11:1 and 11:11): "by no means" ( $\mu \dot{\eta} \gamma$ $\varepsilon \dot{v} 0 \iota \tau 0)$, and on a verse dear to Augustine: "For the Lord will not reject his people; he will never forsake his inheritance" (Psalm 94:14), to invoke the irrevocable character of God's election of the Jewish people. In the words of Vieira: "This people and inheritance of God is the people and nation of the Hebrews, whose Patriarchs God promised them to remain His inheritance and that He never will cast them away from Him." ${ }^{49}$ For this reason, not only did Paul compare the Jews to a cultivated olive tree and the Gentiles to a mere oleaster; the "Apostle to the Gentiles" even claimed that the wild olive tree was "un-naturally" grafted into the cultivated "natural" one.

These comments led to the Inquisition's accusation that Vieira maintained the inherent sanctity of the Jewish people. He rejected this claim, explaining that by "natural" Paul intended the prolonged familiarity the Hebrews had with God in the Bible, which was lacking in the Gentiles. It was, he said, a privileged historical relationship inherited from their ancestors "almost naturally" (como natural). At the same time, he conceded that if, according to Paul, Jews worshipped God "according to nature" ( $\varkappa \tau \tau \dot{\alpha} \varphi v \sigma \sigma \nu)$ and Gentiles "against nature" ( $\pi$ apd $\varphi \dot{v} \sigma \tau \nu$ ) (Romans 11:21,24), these terms should be understood "not as being natural or following nature, but rather to be more in accordance with it, like the fact that sons usually inherit the vices of their parents." ${ }^{50}$ By explaining that Jews simply have a penchant towards God, Vieira was avoiding theological or biological determinism. As we shall see, however, whereas Paul's loose concept of "nature" ( $\varphi v \sigma \iota \zeta)$ meant the order of things as they appear before the observer (including customs and conventions), ${ }^{51}$ Vieira's "nature" was more grounded on heritable factors (biological, climatological, and educational) of the sort claimed by the Spanish physician Juan Huarte de San Juan (1529-88) in his immensely popular Examen de ingenios para las ciencias (Baeza, 1575). ${ }^{52}$

49 Vieira, Apologia, 136-39; Vieira, História do futuro, 56o-61; Vieira, Defesa perante o Tribunal do Santo Ofício, 362-66.

50 Muhana, ed., Autos do processo de Vieira na Inquisição, 339-49.

$51 \quad$ Helmut Koester, " $\varphi v \dot{\sigma} \varsigma \varsigma \tau \chi \lambda$," in Theological Dictionary of the New Testament, ed. Gerhard Kittel and Geoffrey W. Bromiley, 9 vols. (Grand Rapids: W. B. Eerdmans, 1965-74), 9:251-77.

52

Wishing to leave room for human free will and God's grace, Huarte de San Juan adopted biblical ideas and themes, including from Paul's Epistles. See Jon Arrizabalaga and Maria Laura Giordano, "Cristianismo paulino en Huarte de San Juan: Meritocracia y linaje en 
Yet Vieira recalled that such a "natural" proclivity was radically placed into question by the refusal of most Jews to accept Christ as their long-awaited Messiah. It is for this reason that their final conversion to Christianity was compared by the Apostle to the Gentiles to the resurrection of the dead (Romans 11:15). At the same time, in his defense before the Holy Office, he explained that when he fully understood Romans 11:11 and 11:25-26 ("because of their transgression, salvation has come to the Gentiles to make Israel envious;" "Israel has experienced a hardening in part until the full number of the Gentiles has come in, and in this way all Israel will be saved"), he understood the ambivalent character of such "transgression" ( $\pi \alpha \rho \alpha \pi \tau \dot{\omega} \mu \alpha \tau)$ and "hardening" ( $\pi \dot{\omega} \rho \omega \sigma \iota \zeta)$ : a terrible fault that turned to be a blessing. By the same token, he wondered whether preaching was a sine qua non requirement to obtain the final conversion of the Jews, or whether they would become devoted Christians by virtue of the prior conversion of "the full number of the Gentiles." ${ }^{3} 3$ Be as it may, it is apparent that following Vieira, this "marvelous event" would transform the "stubborn" and "blind" Hebrews into "the brightest light and radiance of the Church." For, in the Fifth Empire, converted Jews would become the most fervent propagators of Christ on earth, like the Jewish Apostles in times of the primitive church. ${ }^{54}$

Moreover, residue of this reenacted spiritual excellence would reappear in the eschatological times of the Antichrist, when many of these outstanding Christians of Jewish origin would stand again in the forefront of Christ's final battle against evil. ${ }^{55}$ In other words, whether living in the times of the Old

el Examen de ingenios para las ciencias (Baeza 1575-1594)," Hispania sacra 72, no. 146 (2020): 363-75.

On the one hand, Vieira admitted "that the most efficacious means to convert the Jews is to press the conversion of the Gentiles" (Vieira, Defesa perante o Tribunal do Santo Oficio, 340); "St. Paul revealed [...] about the conversion of the Jews, saying that they will persist in their blindness until the Gentiles will receive the faith, and after these will be admitted as members of the Church, Jews will also come in" (Vieira, Apologia, 151). On the other hand, he envisioned writing a catechetical tract specifically addressed to converso Judaizers and practicing Jews called Conselheiro secreto (Secret counselor) and explicitly advised to kindly convince suspected New Christian Judaizers (Muhana, ed., Autos do processo de Vieira na Inquisição, 229, 334).

Muhana, ed., Autos do processo de Vieira na Inquisição, 181; Vieira, Apologia, 142-45; Vieira, Defesa perante o Tribunal do Santo Ofício, 421-23. Cf. Thomas M. Cohen, "Millenarian Themes in the Writings of Antonio Vieira," Luso-Brazilian Review 28 (1991): 23-46; Cohen, "Judaism and the History of the Church in the Inquisition Trial of António Vieira," LusoBrazilian Review 40 (2003): 67-78. explained that there would be two universal conversions of humankind: the first before the Antichrist and the second during the Antichrist (Vieira, Defesa perante o Tribunal do 
and New Testaments, throughout the history of the church, in the prospective harmonious Fifth Empire, or even during the turbulent moments of the Eschaton, Jews, either as committed believers or as stubborn sinners, appear in Vieira's writings as maintaining a privileged relationship with God, characterized by the unique intensity of its fluctuations, either between Israel's fidelity and betrayal or by God's particular cherishment and severe punishments. As I mentioned at the beginning of this article, the question remains: how could Vieira reconcile such an idiosyncratic understanding of the Jews with Paul's universalism? I argue that Vieira's advocacy on behalf of Bandarra's prophecies in large part elucidates his views on Paul's Judeo-Gentile universalism.

When Vieira faced the inquisitorial suspicion that the shoemaker of Trancoso could have had Jewish origins (which were purportedly reflected in his "Judaizing" Trovas), he first replied by saying that nothing of the sort had been proven in Bandarra's own inquisitorial trial. ${ }^{56}$ Although the suspicion was at the most an unfounded rumor, Vieira nevertheless quoted Romans 10:12 ("For there is no difference between Jew and Gentile, the same Lord is Lord of all and richly blesses all who call on him"), to argue that ethnic origins were not an obstacle to becoming a genuine Christian prophet. If before Jesus Christ human beings could rightly be classified according to their country of birth and cultural belonging (diferentes nações), the regenerative virtues of faith and baptism erased the theological relevance of ethnic difference. In Christianity, "everybody is from the same nation and of the same blood." ${ }^{7}$ Moreover, he brought an interpretation of Augustine to the effect that Jesus Christ was born a Jew with some Gentile female ancestry (i.e. Rahab and Ruth) in order to himself promote his project of Judeo-Gentile reunification. ${ }^{58}$ For this reason, the Jesuit did not exclude the possibility that Bandarra, the modern apostle of

Santo Ofício, 408-64; Vieira, A Chave dos Profetas, livro segundo e livro terceiro, 316-21 = Peloso, La Clavis prophetarum di Antonio Vieira, 452-54).

In the Livro anteprimeiro da história do futuro, Vieira rejected Bandarra's Jewish origins (Vieira, História do futuro, 368-69). For a transcription of Bandarra's inquisitorial trial, in which he was never accused of having Jewish ancestry, see Arnaldo da Soledade ed., Processo de Gonalo Annes Bandarra, çapateiro da villa de Trancoso (anno de 1541) (Trancoso: Câmara Municipal de Trancoso, 1996).

57 Vieira, Apologia, 6o; Vieira, Defesa perante o Tribunal do Santo Ofício, 321.

$5^{8}$ Augustine of Hippo, Expositions of the Psalms 73-98 (vol. III/18), in The Works of Saint Augustine: A Translation for the 21st Century, ed. Maria Boulding and John E. Rotelle (New York: City Press, 2002), 87.8.4. This interpretation was also evoked by the Jewish convert Alonso de Cartagena (1384-1456), bishop of Burgos, against the anti-converso laws of Toledo of 1449 (Bruce Rosenstock, "Alonso de Cartagena: Nation, Miscegenation, and the Jew in Late-Medieval Castile," Exemplaria 12 [2000]: 185-204). 
Judeo-Gentile fraternity, could also have had New and Old Christian "mixed blood" in his veins. ${ }^{59}$

At the same time, he interpreted Paul's Judeo-Gentile union as a long historical process that would only be fully accomplished during the Fifth Empire. Until then, Jews and Gentiles were largely destined by God to remain as separate "nations" living in constant animosity, as was prefigured by the story of Isaac's twin sons, Jacob and Esau, until their reconciliation (Genesis 25 and 33). ${ }^{60}$ This last fraternal historical stage, however, would primarily result from a shared belief in Christ, and would not necessarily be a byproduct of Judeo-Gentile miscegenation. ${ }^{61}$ In Vieira's words: "In the same way that walls which are related by the same corner become united by this token, these two peoples united by Christ will bond together by union or unity of faith, thus becoming one people." 62

It is true that Vieira never abandoned the conviction that baptized Jews could intermarry with baptized Gentiles and be fully integrated into Christian society as indistinct members of the same "mystical body." ${ }^{33}$ The story of the beginning of Christianity in the Iberian peninsula was a good historical example. Employing antiquarian and historical sources, Vieira recalled that James the Apostle was helped by local Jews to spread the Gospel in Spain and establish the first church in Iberia. These baptized Sephardim, however, never became a distinct sub-category of Judeo-Christians. Rather, they seemingly disappeared as a result of their successful integration. ${ }^{64}$

Moreover, the proliferation of marriages between Old and New Christians during King Manuel's reign was a revealing sign that announced the upcoming Fifth Empire under the Portuguese aegis. ${ }^{65}$ During his inquisitorial trial, however, he confessed that he was nevertheless disturbed by the high rate

59 Vieira, Apologia, 70; Vieira, Defesa perante o Tribunal do Santo Ofício, 321.

6o In this respect, Father Vieira evoked the Parable of the Prodigal Son (Luke 15:11-32) (Vieira, Defesa perante o Tribunal do Santo Ofício, 316-18).

61 Vieira, Apologia, 116-28.

62 Vieira, Defesa perante o Tribunal do Santo Oficio, 316-18.

63 Claude B. Stuczynski, "Harmonizing Identities: The Problem of the Integration of the Portuguese Conversos in Early Modern Iberian Corporate Polities," Jewish History 25 (2011): 229-57; Stuczynski, "From Polemics and Apologetics to Theology and Politics: Alonso de Cartagena and the Conversos within the 'Mystical Body," in Conflict and Religious Conversation in Latin Christendom: Studies in Honour of Ora Limor, ed. Ram Ben Shalom and Israel Yuval (Turnhout: Brepols, 2014), 253-77.

64 Vieira, História do futuro, 203-8. Cf. Adam G. Beaver, "From Jerusalem to Toledo: Replica, Landscape and the Nation in Renaissance Iberia," Past and Present 218 (2013): 55-90.

65 Vieira, Defesa perante o Tribunal do Santo Ofício, $5^{67}$. 
of these "mixed marriages."66 Moreover, he interpreted Trova n. 11, in which Bandarra denounced the greediness (cobiça) of the nobility (fidalgos) by corrupting their purity of blood (pureza de sangue) for money, as referring to marriages between members of the Old Christian aristocracy and wealthy New Christians. Coming from a passionate advocate of the converso cause, these astonishing affirmations call for clarification. ${ }^{67}$

I previously argued that Vieira's Pauline prophetic views required that many Jews and Gentiles would remain distinct until the Fifth Empire. ${ }^{68} \mathrm{He}$ also believed that after Jesus's coming, the main role of Gentile believers in Christ was to advance humankind's salvation by spreading the Gospel, and that Portugal had been divinely chosen to complete this task. It is then unsurprising that the Portuguese salvific "hidden king" should be an Old Christian. ${ }^{69}$ After all, the leading historical role God conferred to Portugal in the battle of Ourique and confirmed by Bandarra's Trovas was quia a Gentile kingdom. It was one thing to salute Jews, individually and in groups, who joined a preponderantly Gentile church of their own free will, and another to uncritically welcome huge masses of forcefully baptized New Christians who could blur the "Gentile" character of "chosen" Lusitania. Although it was a positive sign of the upcoming Fifth Empire, the abrupt constitution of a large group of Christians of Jewish origin before that final historical stage endangered the fulfillment of Portugal's soteriological role because of precociously advanced miscegenation.

According to Vieira, the Inquisition found so many heretical Judaizers among the New Christians due to a design of divine providence, revealed by Paul in Romans 11, to respect the order and rhythms of Gentile and Jewish conversions. This is what Vieira claimed in Rome in 1671 by interpreting Isaiah 42:25 ("So he poured out on them his burning anger, the violence of war. It enveloped them in flames, yet they did not understand; it consumed them, but they did not take it to heart") as a prophecy foretelling the inquisitorial activities against the

66 Muhana, ed., Autos do processo de Vieira na Inquisição, 108.

$67 \quad$ These words probably explain why Vieira could be posthumously interpreted as supporting anti-converso laws of purity of blood. See Herman Prins Salomon, "Father António Vieira (1608-1696) in Inquisitorial Perspective 1736-1746," in In the Iberian Peninsula and beyond: A History of Jews and Muslims (15th-17th Centuries), ed. José Alberto R. Silva Tavim et al., 2 vols. (Cambridge: Cambridge Scholars Publishing, 2015) 2:220-35. always stay distinct until the last act of the great tragedy of the world, in which both figures will appear in that theatre, holding hands together in union and unity of the same faith in celebration of the last ceremony of the marriage and coronation of Christ in His consummated empire" (Vieira, Defesa perante o Tribunal do Santo Ofício, 411). 
New Christians. As Vieira confessed: "I am not too surprised by the blindness and obstinacy of the Jews [Iudaeorum], which are neither softened by the fire nor enlightened by the flames, because it is still far away the time promised by the Apostle, when everybody [...] will be enlightened after removing the veil."70 This reference to the Second Letter to the Corinthians 4:3-4 ("And even if our gospel is veiled, it is veiled to those who are perishing. The God of this age has blinded the minds of unbelievers, so that they cannot see the light of the gospel that displays the glory of Christ, who is the image of God") implied that this notorious enemy of the Portuguese Inquisition acknowledged that among the New Christian prisoners of the Holy Office were many genuine Judaizers. ${ }^{71}$ I even assume that for him, the question of the religious sincerity of the conversos would be totally resolved only when Christ would reign on earth, as an integral part of the final and sincere conversion of the Jews. Open Jews and New Christians, genuine or not, were part of the same historical and soteriological process, as all of them were God's chosen heirs of Israel.

This last point leads me to argue that Vieira's views also revealed much of the dialectical way in which the Apostle to the Gentiles conceived his community of Jewish and Gentile believers in Christ. Since only the former were heirs of God's historical covenant, Paul had to invent a second category for the latter by reinterpreting the Old Testament meaning of Gentiles as "nations" (E⿱ $\mathcal{q} v \eta$, gentes, (גויים) to denote non-Jews who actually or potentially join Christ. Much like Paul, Vieira also defined Gentiles as the diversity of non-Jewish multiple "nations" who become amalgamated as a single group by their adherence to Christ. ${ }^{72}$

Moreover, his reconstruction of Paul's community of Jewish and Gentile believers also entailed an intensification of their differences (Jews quia God's biblical "chosen people" and Gentiles as a single category of non-Jews newly "chosen" by their faith in Christ) before becoming one Christian people. ${ }^{73}$ Paul's "neither Jew nor Greek" ("Greek" intended as a metonymy for "Gentile")

Vieira, A Chave dos profetas, Livro Segundo e Livro Terceiro, 136 (= Peloso, La Clavis prophetarum di Antonio Vieira, 277).

71 This implies that Vieira's struggle against the Portuguese Inquisition was not on the grounds that all the convicted New Christians were good Catholics. In light of this excerpt, it rather appears that our Jesuit stood against a biased Holy Office, which did not properly discern between the innocent and the guilty, employing arbitrary harshness instead of evangelical sweetness. Moreover, Vieira also acknowledged that converso exclusion from ecclesiastical offices and orders on "purity of blood" criteria (including his own Society of Jesus) "was grounded on the presumption and experience of the feigned religious faith of many of them" (Vieira, Defesa perante o Tribunal do Santo Ofício, 446). Vieira, Defesa perante o Tribunal do Santo Ofício, 316-18.

73 Adi Ophir and Ishay Rosen-Zvi, Goy: Israel's Multiple Others and the Birth of the Gentile (Oxford: Oxford University Press, 2018), 147-48. 
simultaneously combined the "revocation of statuses in order to hold together the Jew and the gentile without erasing the memory of their separation." ${ }^{74}$

I believe that this convergence of Jews and Gentiles leaves residue of Gentileness and Jewishness within Paul's community of Christ-believers. For later theologians and thinkers, who interpreted the Epistles of the Apostle to the Gentiles without the same eschatological urgency and from the historical perspective of a long-lasting, institutionalized church, which had become primarily associated with Gentiles and not with Jews (as in Paul's times), ${ }^{75}$ that way of simultaneously erasing and evoking ethnic difference enhanced the question of resilient Jewishness. ${ }^{76}$ For, if the relationship between Gentileness and Christianity was organic, self-evident, and mutually intertwined, Jewishnesswhich after the church fathers became an inner threat for Christians, associated with debased materiality, carnality, and legalism (by broadening the

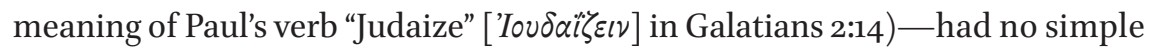
way to find a constructive role within the church. ${ }^{77}$ Pro-converso writers and thinkers such as Vieira brought up Paul's Epistle to the Romans precisely to question such unilateral views by recalling the positive role played by Jews in major moments in the history of salvation. But for the prophetic thinker Vieira, Jewishness also entailed an uninterrupted contribution to that historical process which unfolded along the overt avenues laid out by Gentiles (i.e., leading the church and employing political power).

I argue how and why, for Vieira, Jewishness was channeled in the material sphere - and, more specifically, in the economic domain—as an ambivalent and oblique way for Jews to act as constructive agents of history.

\section{Jewishness as (Positive) Materialism}

Arguably, one of Vieira's most surprising views is his identification of Jews and New Christians with a natural penchant for riches. This propensity was for him

\footnotetext{
74 Ophir and Rosen-Zvi, Goy, 158.

75 Denise Kimber Buell, Why This New Race: Ethnic Reasoning in Early Christianity (New York: Columbia University Press, 2005); Paula Fredriksen, When Christians Were Jews: The First Generation (New Haven: Yale University Press, 2018).

76 Claude B. Stuczynski, "Converso Paulinism and Residual Jewishness: Conversion from Judaism to Christianity as a Theological-Political Problem," in Bastards and Believers: Converts and Conversion between Judaism and Christianity, ed. Pawel Maciejko and Theodor Dunkelgrün (Philadelphia: University of Pennsylvania Press, 2020), 112-34.

77 David Nirenberg, Anti-Judaism: The Western Tradition (New York: W. W. Norton \& Company, 2013).
} 
a means of propelling faith. Already in the Old Testament, he explained, God forbade usury between the Israelites (Deuteronomy 23:20), because by this interdiction they were forced to leave their homeland in Palestine and dwell scattered among the Gentiles, where they could freely satisfy their material appetites. Well before Christ, diasporic Jews thus paved the way to the Gospel by spreading the faith in a single God while doing business. ${ }^{78}$ Much of the same occurred afterwards, when, in the time of the apostles, Jewish believers in Christ became the initial evangelizers of their Gentile neighbors. ${ }^{79}$

Such a paradoxical manner of promoting spirit through matter was not uniquely Jewish. It stemmed from a principle of divine providence: "When God wishes to bring a religion from one kingdom to another, He puts the faith in the back of interest," because "preachers bring the faith to strange kingdoms and commerce takes the preachers on its backs." 80 It was not a matter of chance that Manuel I was the first Portuguese monarch to proudly add "Lord of commerce and navigation of Arabia, Persian and India" to his numerous titles. More than any of his predecessors, this king knew how to spread Christianity through economic exchange. Much like the ancient Jewish and Judeo-Christian businessmen, Vieira says of the early modern Portuguese merchants (many of them New Christians): "When they return [from distant lands] they bring gold, silver, pearls, diamonds, rubies; and when they go there, they take with them the faith in Christ, a hope from heaven, the evangelical truth, the sacraments, grace, and salvation." 81 The fact that God placed so much wealth in distant lands of East and West, as if these regions kept "almost all the treasures of the world," was aimed to provoke ambition (avaritia) among Portuguese and other European adventurers to cross the dangerous oceans. In this way, the voracious quest for wealth in "barbarian" and strange lands was instrumental to evangelical activity. ${ }^{82}$

It is true that other pro-converso mercantilist writers, such as the Portuguese New Christian arbitrista Duarte Gomes Solis (c.1562-1632), similarly emphasized the synergy between the missionary and the merchant as an apologetic means of supporting the social integration of the New Christian entrepreneurial elites into Iberian society. ${ }^{83}$ However, Vieira explained, this was part of a broader mechanism,

78 Vieira, História do futuro, 497-98.

79 Vieira, História do futuro, 501-4.

8o Vieira, História do futuro, 497.

81 Vieira, História do futuro, 498.

82 Vieira, $A$ Chave dos profetas, 354-55 (= Peloso, La Clavis prophetarum di Antonio Vieira, 194).

83 Nathan Wachtel, “The 'Marrano' Mercantilist Theory of Duarte Gomes Solis," Jewish Quarterly Review 101 (2011): 164-88; Claude B. Stuczynski, "Portuguese Conversos and the Manueline Imperial Idea: A Preliminary Study," Anais de história de Além-Mar 14 (2013): 45-63. 
both divine and human, which employs dialectical tensions and ambivalences as positive catalyzers. No wonder that Vieira chose the term "covetousness" (cobiça, cupiditas) to denote that serpentine and oblique avenue of spreading Christian virtue through one of the seven deadly sins. On the one hand, Vieira's "covetousness" echoes early modern Iberian discourses that perceived human experience through the problematic prism of real and symbolic wealth. ${ }^{84}$ On the other hand,

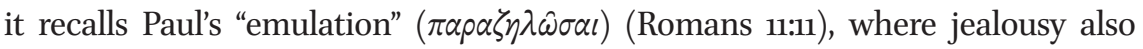
appears as a paradoxical means of accelerating history. At the same time, that "ability to do business and the insatiable desire for increasing riches" were, to our Jesuit, "natural" in Jews and only circumstantial or epochal among Gentiles. ${ }^{85}$ Jews, said Vieira, were the worthy sons of their ultimate forefather Jacob/Israel, who, from selling a single lentil stew to his brother Esau in exchange for his primogeniture (Genesis 25:29-34), became the richest man in the world. ${ }^{86}$

In other words, Jewishness simultaneously entailed a "natural" penchant towards God-temporally suspended by a "hardening" that enabled the salvation of the Gentiles - and a "natural" tendency toward greed, which continuously promotes mission and evangelization. I argue that this complex mirror game unfolds just two of the most ostensible expressions of Jewishness. In order to discover other meanings and implications, it is worth looking at Vieira's comments on the Ten Lost Tribes of Israel. ${ }^{87}$

As previously mentioned, the final conversion of the Jews during the Fifth Empire or the reign of Christ on earth was said to include the discovery, reunion, and baptism of those "hidden" Hebrew brothers. The issue of the Lost Tribes of Israel was a major early modern theological-political myth. It simultaneously allowed Europeans to justify imperial projects and fueled messianic hopes, millenarian expectations, and anxieties. For Vieira's main Jewish collocutor, Rabbi Manasseh ben Israel, refusing to identify the Ten Lost Tribes with the Amerindians, as many others did, was a means of depicting Jews as Europeans through intellectual and aesthetic Westernization..$^{88}$

$84 \quad$ Lía Schwartz Lerner, "El motivo de la 'auri sacra fames' en la sátira y en la literatura moral del siglo XVII," in Las Indias (América) en la literatura del Siglo de Oro, ed. Ignacio Arellano (Kassel: Reichenberg, 1992), 51-70.

85 Vieira, A Chave dos profetas, 26o (= Peloso, La Clavis prophetarum di Antonio Vieira, 139).

86 Vieira, História do futuro, 497. Vieira's archetypical identification of the Jews with Jacob was not fortuitous. Jacob was the father of the twelve sons of Israel. This was not the case with Jacob's grandfather Abraham, who, according to Romans 4:12-13, was the father of believers, whether circumcised or not; nor with Jacob's father Isaac, who engendered "two nations [...] and two peoples" through his sons Jacob and Esau (Genesis 25:23).

$87 \quad$ Vieira, Apologia, $155^{-88 .}$

88 Richard H. Popkin, "The Rise and Fall of Jewish Indian Theory," in Menasseh ben Israel and His World, ed. Yosef Kaplan et al. (Leiden: Brill, 1989), 63-82. 
In his Hope of Israel (1650), he explained that

is more false that they [i.e. Amerindian peoples] are Israelites, who have forgotten circumcision and their rites. For they [i.e. the Lost Tribes of Israel] are of a comely body and of good wit, as says Doctor Juan de Huarte in his book which is called Examen de ingenios (cap. 14). ${ }^{89}$ But contrarily, all men know that the Indians are deformed, dull, and altogether rude. And we have abundantly shown with how great study and zeal the Israelites have kept their language and religion out of their country."90

Scholars have suggested that the rabbi's messianic views influenced the Jesuit's "millenarian" expectations. ${ }^{91}$ This leads me to make an additional, albeit hesitant conjecture: ben Israel's idealized portrait of the Lost Tribes of Israel may have propelled some of Vieira's own perceptions of Jewishness. ${ }^{92}$

In his comments on the prophecies to be fulfilled during the last historical stage, Vieira summarized the strange story of the Ten Lost Tribes of Israel in the

This numeration follows the Spanish edition of Baeza, 1594. In the princeps edition of Baeza, 1575, it corresponds to chapter 12. Juan Huarte de San Juan, Examen de ingenios para las ciencias, ed. Guillermo Serés (Madrid: Cátedra, 1989), 493-523.

Menasseh ben Israel, The Hope of Israel, ed. Henry Méchoulan and Gérard Nahon (Oxford: The Littman Library of Jewish Civilization, 2004), 161. In his later apologetic tract to Oliver Cromwell, "Humble Addresses" (1655), ben Israel celebrated three main characteristics of the Jews: "Profit, they may receive from them; Fidelity they hold towards their Princes; and their Nobleness and purity of their blood." Regarding "profit," he further explained: "It is a thing confirmed that merchandizing is, as it were, the proper profession on the Nation of the Jews. I attribute this in the first place, to the Particular Providence and mercy of God towards his people: for having banished from their own Country, yet not from his Protection, he hath given them, as it were, a naturall instinct" (Lucien Wolf, ed., Menasseh ben-Israel's Mission to Oliver Cromwell, being a Reprint of the Pamphlets Published by Menasseh ben-Israel to Promote the Re-Admission of the Jews to England, 1649-1656 [Cambridge: Cambridge University Press, 2012], 81).

Silvano Peloso dates the first stages of conception of Vieira's major "millenarian" book, the Key of Prophets, to between 1646 and $165^{2}$ (Peloso, Antonio Vieira e l'impero universal, 58). Ana Paula Banza thinks in terms of a messianic "impetus" as the result of Vieira's encounter with ben Israel (Banza, “Da 'História do futuro' à 'Clavis prophetarum,'” 2:93-107, here 96). Humanitas, fapesp, 2016) António José Saraiva, "António Vieira, Menasseh ben-Israel et le Cinquième Empire;" Adma Muhana, Uriel da Costa e a nação portuguesa: Edição diplomática e estudo do "Exame das tradições fariseias" (São Paulo:, FAPESP, 2016), 73-75; Luís Filipe Silvério Lima, "Prophetical Hopes, New World Experiences and Imperial Expectations: Menasseh Ben Israel, António Vieira, Fifth-Monarchy Men, and the Millenarian Connections in the Seventeenth-Century Atlantic," Anais de historia de AlémMar 17 (2016): 359-408. According to Steven Nadler, however, "If Menasseh did introduce the subject [to Vieira, about the Ten Lost Tribes of Israel purportedly discovered in the New World], he did not make much of it" (Steven Nadler, Menasseh ben-Israel, Rabbi of Amsterdam [New Haven: Yale University Press, 2018], 139). 
Fourth Book of Esdras (esp., chap. 13). Punished by God for committing idolatry, they were expelled from the Holy Land by the Assyrian king Salmanazar (i.e., Shalmaneser V, r.727-22 BCE) to "a deserted land, far away from any exchange or relationship with other nations, in order to keep from then onwards the law of the true God."93 Much like ben Israel, Vieira reviewed different opinions regarding their actual geographical localization. On one issue the priest and the rabbi were in complete accord: the atoning seclusion of the Ten Lost Tribes of Israel implied endogamy, and therefore the preservation of their idiosyncratic Hebrew traits. For this reason, Vieira also claimed that Amerindians could not be the scions of the lost Israelites. On the one hand, he said, many of the native Americans were "barbarians" "who looked more like brutes than humans." Even the wisest among them could be only compared to an average European. Conversely, it was widely known that Jews were characterized by their sharpness and astuteness (agudos e astutos como os judeus). This was another way to confirm Huarte de San Juan's assessment regarding the ability of biblical Hebrews: "and of all their children and posteritie prooued sharp and great of wit in matters appertaining to this world" (todos sus hijos y descendientes salieron agudos y de grande ingenio para las cosas de este siglo), such as medicine. ${ }^{94}$

Following a similar set of explanations, Vieira acceded that climate could modify the color of the skin, the physical appearance of men and women, and even the hairiness of the body. But, he wondered, how could it be that even a single Hebrew word was not preserved, not to mention the capacity for reading and writing, or any remembrance of their motherland and exile? Moreover, if vices are the more difficult traits to uproot from a specific group of people, how could be possible that Amerindians did not preserve any of the main visible Jewish oddities: "covetousness" (cobiça), "interest" (interesse) or "traces of selling and buying" (traças de comerciar e adquirir)? ${ }^{95}$ For the same reason, he added, the Lost Tribes of Israel could not be situated in Central Asia amidst the Tartars, whose customs (such as eating raw food) would have been alien to biblical Israelites. Contrary to the natural penchant of the Hebrews, Tartars opted

93 Vieira, Apologia, 161.

94 Vieira, Apologia, 168; Huarte de San Juan, Examen de ingenios: The xamination of mens vvits in whicch, by discouering the varietie of natures, is shewed for what profession each one is apt, and how far he shall profit therein (London: Adam Islip for Richard Watkins, 1594), 194 (= Huarte de San Juan, Examen de ingenios para las ciencias, 516). 
to live in poverty, avoiding the use of gold, silver, or money. ${ }^{96}$ Covetousness and merchandizing thus appear interrelated with wit and astuteness. ${ }^{97}$ At the same time, Jewishness comprised other expressions of attachment to the material world, such as the steadfast preservation of their ancestral rites "by natural tenacity" (por natureza tenacíssima). ${ }^{98}$

Vieira's portrait of Jewishness certainly stemmed from a widespread stereotype of Jews and conversos. ${ }^{99}$ At the same time, it also seems directly taken from the Jesuit José de Acosta's (1540-16oo) great geographical and ethnographical work on the New World, Historia natural y moral de las Indias (The natural and moral history of the Indies). This work, printed in Seville in 1590, was an important source for Rabbi ben Israel as well. According to Acosta,

Ignorant folk commonly believe that the Indians proceed from the race of the Jews because they are cowardly and weak and much given to ceremony, being acute [agudos], and liars [mentirosos] [...], but all these are very idle conjectures and have more evidence against them than for them. We know that Hebrews used writing, but among the Indians there is no trace of this. The others were very fond of money; these pay it no heed [...]. Moreover, how can it be, when the Jews have been so assiduous in preserving their language and ancient traditions, to the point that in every part of the world where they live today they differ from the rest, that in the Indies alone they have forgotten their ancestry, their law, their ceremonies, their Messiah, and finally all their Judaism [judaísmo]?100

For Vieira, all of these "natural" traits explain why Jews have such great difficulty in accepting a crucified God-Messiah, preferring to endlessly wait for a portentous political savior who will lead them back to their ancestral motherland with all the terrestrial goods announced by their prophets. Our Jesuit

96 Vieira, Apologia, 173 .

97 At the same time, Vieira mentioned Eusebius of Caesarea's Praeparatio evangelica (book 9, chapter 3), to remind that even the great Aristotle was taught by Jews (Vieira, A Chave dos profetas, 261 = Peloso, La Clavis prophetarum di Antonio Vieira, 140).

98 Vieira, História do futuro, 500.

99 Claude B. Stuczynski, “Judaïcité et richesse dans l'apologétique des 'conversos' portugais: Un argument contre-culturel," Atalaya 14 (2014), http://atalaya.revues.org/1232 (accessed December 25, 2020).

100 I quote almost verbatim from the following English translation: José de Acosta, Natural and Moral History of the Indies: Chronicles of the New World Encounter, ed. Jane E. Mangan (Durham: Duke University Press, 2002), 69-70. Occasionally, I have modified the translation, putting the original Spanish words in square brackets. 
admitted that any other nation or people with a comparable background and destiny would probably react in a similar way. But this was particularly true of the Jewish people, because of "the natural inclination of the Hebrews, who more than other men are gripped to the worldliness of earth and life, being so notorious in the Scriptures, as it can be particularly seen in the prophets."101

Vieira not only believed that some of these expectations could be accepted by church authorities; they should be Christianized. It is likely that this was one of the main lessons he learned during his encounters with Rabbi ben Israel. Of course, Vieira stated, professing Jews and converso Judaizers err in not believing that the Messiah had already come in the person of Jesus Christ and in continuing to think that their salvation depends on the fulfillment of the Law of Moses. However, they are correct in waiting for those biblical prophecies that do not contradict Christian faith or moral principles, including the "discovery" of the Ten Lost Tribes of Israel, the return of the Jews to the Holy Land, and the reconstruction of the Temple of Jerusalem. ${ }^{102}$ For what Jews call the future coming of the Messiah is none other than Christ's glorious return on earth in the last stage of history. ${ }^{103}$

As a trained Jesuit missionary, Vieira suggested giving to these prospective converted Jews concessions like those granted by princes and popes to neophytes and repented heretics from different religious backgrounds in order to support their organic integration within the church and society. Vieira called to issue a papal dispensation, or concordata, aimed at reconciling their sincere belief in Christ and adherence to the practices of the Catholic Church with their Jewish idiosyncrasies. ${ }^{104}$

Moreover, in a long section of the second part of the Key of Prophets, called "Tractate on Ezekiel's Temple and its literal interpretation," Vieira hypothesized about what would happen to those proclivities in the last stage of history. ${ }^{105}$ Following the prophecies of Ezekiel 40-48, Isaiah 6o, and Psalm 5o, our Jesuit claimed that after the final return of the Jews to Palestine as converted

101 Vieira, Defesa perante o Tribunal do Santo Ofício, 466.

102 Vieira, Defesa perante o Tribunal do Santo Ofício, 465.

103 Muhana, ed., Autos do processo de Vieira na Inquisição, 226-27.

104 Vieira claimed to have received permission to seek such concordata or dispensation from the authoritative Scholastic jurist and theologian, the Jesuit Francisco Suárez (15481617) (Vieira, Defesa perante o Tribunal do Santo Ofício, 46o-72). Vieira offered several examples of exceptional dispensations aimed to conciliate Catholicity with local customs or circumstantial sensibilities (Vieira, A Chave dos profetas, 166-79 = Peloso, La Clavis prophetarum di Antonio Vieira, 297-304).

105 Vieira, A Chave dos rofetas, 149-206 = Peloso, La Clavis prophetarum di Antonio Vieira, 284-319. 
Christians, the Temple cult in Jerusalem would be restored. ${ }^{106}$ Understanding the audacity of this assertion, which diverged from authoritative typological readings of Augustine and risked a "Judaizing" misunderstanding, Vieira explained that the temple service in Jerusalem would be led by Catholic priests to the glory of the Trinitarian God rather than on behalf of the abrogated Law of Moses. On the one hand, this was a literal requirement of the prophets. On the other hand, the temple cult would crystalize that fraternal unity announced by Paul in his Epistles, welcoming both Jews and Gentiles to simultaneously perform ceremonies of the "New Law" (i.e. the Eucharist) along with those of the "Old Law" (perhaps sacrifices), and thereby creating the effect of a beautiful chiaroscuro canvas (tanquam ex vivis coloribus et mortuis umbris depicta). ${ }^{107}$

Not only is this God's design, it would also be a wise concession from the Catholic Church to baptized Jews, because they have "the immemorial habits of a people habituated to be taught by God only through external and perceptible signs." ${ }^{108}$ Temple worship in Jerusalem would thus be the optimal way to express the most sincere and fervent Christian feelings in more judaico.

Vieira likened the world to a musical instrument, and the different "nations" and kingdoms to its various strings. ${ }^{109}$ Moreover, in his view, conversion to Christianity encountered a major challenge in the idiosyncratic habits with which human beings are raised from early childhood. In this article, I have claimed that, for Vieira, who was acutely aware of human diversity and common universal patterns, Jews embodied a sui generis group of people due to their unique theological and soteriological role as "chosen others." Vieira's earthly perception of Jewishness endorsed quasi-essentialist approaches, akin to contemporary anti-converso exclusion criteria and traditional anti-Jewish stereotypes. ${ }^{110}$ Nonetheless, his views were positive from both a theological and a teleological standpoint, advancing a vision of Jewishness that avoids the categorical supersessionism found in other forms of Christian historicism

\footnotetext{
106 Vieira, Defesa perante o Tribunal do Santo Ofício, 408-64; Vieira, $A$ Chave dos profetas, $165=$ Peloso, La Clavis prophetarum di Antonio Vieira, 296. Vieira, A Chave dos profetas, 170 = Peloso, La Clavis prophetarum di Antonio Vieira, 299.

108 Vieira, $A$ Chave dos profetas, $191=$ Peloso, La Clavis prophetarum di Antonio Vieira, 311.

109 Vieira, Apologia, 123.

110 Cf. Bruno Feitler, The Imaginary Synagogue: Anti-Jewish Literature in the Portuguese Early Modern World (16th-18th Centuries) (Leiden: Brill, 2015).
} 
(e.g. Hegelianism). ${ }^{111}$ For even if the Law of Moses was definitely abrogated after Jesus's coming on earth, Jews—-whether professing or baptized—are still seen as meaningful historical actors, not fossilized remnants of a bygone era.

Moreover, if the power of God is related to his way of managing the world while increasing his glory, ${ }^{112}$ Jews appear in Vieira's writings as literally fulfilling his "glorious economy" through commerce. I would suggest that Vieira's assumptions about Jewishness are primarily related to his way of perceiving matter. If for his inquisitors "there is no doubt that the damnation of the Angel [i.e. Satan], and the [first] man [i.e. Adam], was due to the aversion of spiritual good and affection to temporal goods,"113 for our Jesuit things were much more ambivalent, dialectical, and complex. Like other Iberian mercantilist thinkers and writers, he even characterized wealth as good, provided it is employed "soberly," "parsimoniously," and "honestly" to better serve society and God.114

Matter will be purified of its evil aspects in that final and supreme stage of history when Jews will leave their proverbial "covetousness," and, channeling their distinctive "acuteness" into spiritual matters, will shine like stars in the Christian skies. In this sense, António Vieira was not only a pro-converso Jesuit who envisioned openly professing Jews and New Christians as serving Christ in their "natural" ways ad maiorem Dei gloriam. Much like Bandarra, his beloved Portuguese prophet, Vieira was also one of those Catholic followers of a longstanding Joachimite tradition, which, according to Robert E. Lerner, paved the way to early modern and modern Christian philosemitism by conceiving of Jews as a positive historical-messianic driving force, and, ultimately, of Jewishness as a terrestrial-spiritual blessing. ${ }^{115}$

111 Joseph Cohen, Le Spectre juif de Hegel (Paris: Galilée, 2005).

112 Giorgio Agamben, The Kingdom and the Glory: For a Theological Genealogy of Economy and Government (Stanford: Stanford University Press, 2011).

113 Muhana, ed., Autos do processo de Vieira na Inquisição, 223-24.

114 Muhana, ed., Autos do processo de Vieira na Inquisição, 236-37, 241-42. Cf. Elvira Vilches, New World Gold: Cultural Anxiety and Monetary Disorder in Early Modern Spain (Chicago: The University of Chicago Press, 2010), 322.

115 Robert E. Lerner, The Feast of Saint Abraham: Medieval Millenarians and the Jews (Philadelphia: University of Pennsylvania Press, 2001); Marjorie Reeves, Joachim of Fiore and the Prophetic Future (New York: Harper \& Row, 1977), chapter 5 . 